\title{
DESIGNING AND TESTING AN ASSESSMENT MODEL OF THE ANTECEDENTS OF CORPORATE ENTREPRENEURSHIP IN PUBLIC AND PRIVATE COMPANIES
}

Alexandre De Araújo Castro ${ }^{1}$

Liliane De Oliveira Guimarães $^{1}$

Paulo Vitor Siffert ${ }^{1}$

${ }^{1}$ Pontifícia Universidade Católica de Minas Gerais - PUC Minas 


\title{
DESIGNING AND TESTING AN ASSESSMENT MODEL OF THE ANTECEDENTS OF CORPORATE ENTREPRENEURSHIP IN PUBLIC AND PRIVATE COMPANIES
}

\begin{abstract}
The purpose of the paper is to analyze instruments for the evaluation of individual entrepreneurial characteristics and organizational conditions and to test these instruments in large organizations. These objectives were established from the literature, lavish in references emphasizing the importance of stimulating entrepreneurial initiatives in large organizations. As the CEAI test has been improved, it was initially chosen to subject the Gletest to a statistical evaluation of validity and reliability. The second part involved applying those instruments to managers of large companies and verify the possible correlations between these antecedents of Corporate Entrepreneurship. The first observation is that the majority of the correlations between the constructs is positive, presenting a tendency to observe higher scores of the entrepreneurial behaviors (Gletest) where higher scores of the organizational factors (CEAI) are observed. Statistical analyses do not identify whether the organizational factors influence the personal entrepreneurial characteristics (PECs) or the other way around.
\end{abstract}

Keywords: Corporate entrepreneurship. Entrepreneurial characteristics. Organizational conditions. Large companies

\section{$1 \quad$ INTRODUCTION}

Scholars of issues related to the competitiveness of organizations have linked corporate entrepreneurship to the process of forming competitive advantages and innovation. They also consider it a key factor in organizations achieving success (BABAK, 2016; FERRAS et al., 2018; KAMAU, 2018; KURATKO; HORNSBY; HAYTON, 2015; KURATKO; MORRIS; SCHINDEHUTTE, 2015), since there is superior performance in organizations that engage in entrepreneurial activities (KAHKKA; KAHRAZEH; ARMESH, 2014; KAMAU, 2018; URBAN, 2017; ZAHRA; JENNINGS; KURATKO, 1999).

Other authors also advocate stimulating entrepreneurial initiatives in mature organizations - intrapreneurship or corporate entrepreneurship (CE) - as an essential element for facing the challenges of constant change and fierce competition (BABAK, 2016; BLOODGOOD et al., 2015; KURATKO; AUDRETSCH, 2013).

Some scholars have explored the process of corporate entrepreneurship from the perspective of obstacles to its development (HORNSBY; KURATKO; MONTAGNO, 1999). In the discussions about entrepreneurial initiatives in organizations, the bureaucratic structure and the conservatism of the large organizations are pointed to as impediments to intrapreneurship (SILVA et al., 2018). Thus, rigid procedures, risk aversion and structural slowness create an inhospitable environment for entrepreneurial initiatives to manifest themselves (REILLY; DIANGELO, 1987). For Kuratko et al. (1993), managers must take 
effective action to overcome these obstacles, and must learn to make bureaucratic standards and entrepreneurial initiatives coexist (KURATKO et al., 2015; SATHE, 1989).

In seeking to identify, in the literature of the area, the factors that influence entrepreneurial initiatives in large organizations, we find that corporate entrepreneurship depends on the interaction between individual and organizational characteristics. The combination of individual entrepreneurial skills and organizational conditions conducive to innovative initiatives represents the background for corporate entrepreneurship. In this sense, our initial interest was in the search for instruments to evaluate the entrepreneurial profile of the individuals and also tools to evaluate the organizational conditions that determine corporate entrepreneurship. However, we did not find any evaluation model or empirical research that identified the degree of presence of the antecedents of entrepreneurship in an organization, through the evaluation of these two dimensions simultaneously.

In this way, this work had two objectives. The first consisted in raising and analyzing instruments for evaluating individual entrepreneurial characteristics and organizational conditions, composing what we could classify into a model for assessing the qualities of corporate entrepreneurship. The second objective was to apply these instruments in large organizations, measuring the degree to which the qualities necessary for intrapreneurship were present. The assumption was that, from the identification of instruments to evaluate the factors necessary for intrapreneurship in both dimensions - individual and organizational - it could be applied in large organizations to assess the background needed for intrapreneurship. This diagnosis could indicate the need for training or changes in internal conditions, with the aim of providing better conditions for developing corporate entrepreneurship.

The establishment of these objectives is justified insofar as the literature on the subject has been lavish in pointing out the need of large organizations, for their business survival and expansion, to invest and stimulate entrepreneurial initiatives, while advocating the need for more research (KURATKO; HORNSBY; HAYTON, 2015).

The article, therefore, is structured as follows: in the next session, item 2, the literature review, we discuss corporate entrepreneurship and present the tools for assessing the antecedents of intrapreneurship. In item 3, we present the methodology used to prepare the work. In item 4, we analyse the results obtained with the statistical refinement of the Gletest instrument (self-evaluation of individual entrepreneurial skills) and with the application of the two tests. Finally, in item 5, we present the conclusions of the study.

\section{THEORETICAL FRAMEWORK}

The literature of the area has shown that, in addition to other factors, intrapreneurship is a function of the entrepreneurial characteristics of the organization's members (HORNSBY et al., 1993; KONTIC; VIDICKI; DOMANOVIC, 2017). Based on a survey in the literature on entrepreneurship by Hornsby et al. (1993) and in studies done by McClelland et al. (1987) and Cooley (1990), we found that, in general, the characteristics and behavior patterns observed in successful entrepreneurs are presented in Chart 1: 


\section{Chart 1 - Personal entrepreneurial characteristics (PECs) and-behaviors indicators, identified by McClelland et al. (1987), reviewed and supplemented by Cooley (1990)}

\begin{tabular}{|c|c|}
\hline PECs & Behaviors indicators \\
\hline Goal Setting (GS) & $\begin{array}{c}\text { - Sets goals and objectives that are personally meaningful and challenging; } \\
\text { - Defines clear and specific long-term goals; } \\
\text { - Sets measurable short-term objectives }\end{array}$ \\
\hline $\begin{array}{c}\text { Moderate Risk Taking } \\
\text { (MRT) }\end{array}$ & $\begin{array}{l}\text { - Deliberately calculate risk and evaluate alternatives; } \\
\text { - Takes action to reduce risks or control outcomes; } \\
\text { - Places yourself in situations involving a challenge with moderate risk }\end{array}$ \\
\hline $\begin{array}{l}\text { Opportunities Seeking } \\
\text { and Initiative } \\
\text { (OSI) }\end{array}$ & $\begin{array}{l}\text { - Does things before being asked or before being forced to by events; } \\
\text { - Acts to extend the business into new markets, products or services; } \\
\text { - Seizes unusual opportunities to start a new business, obtain finance, equipment, } \\
\text { land, workplace; }\end{array}$ \\
\hline $\begin{array}{l}\text { Information Seeking } \\
\text { (IS) }\end{array}$ & $\begin{array}{l}\text { - Personally seeks information from clients, suppliers or competitors } \\
\text { - Does personal research on how to provide a product or service; } \\
\text { - Consults experts for business or technical advice }\end{array}$ \\
\hline $\begin{array}{l}\text { Quality and Efficiency } \\
\text { Requirement (QER) }\end{array}$ & $\begin{array}{c}\text { - Finds ways to do things better, faster and/or cheaper; } \\
\text { - Acts to exceed standards of excellence; } \\
\text { - Develops or uses procedures to ensure that work is completed on time or meets } \\
\text { agreed standards of quality }\end{array}$ \\
\hline Persistence (PER) & $\begin{array}{l}\text { - Takes action in the face of a significant obstacle; } \\
\text { - Takes repeated actions or switches to an alternative strategy to meet a challenge or } \\
\text { overcome an obstacle; } \\
\text { - Makes a personal sacrifice or expends extraordinary effort to complete a job }\end{array}$ \\
\hline Commitment (COM) & $\begin{array}{l}\text { - Makes what is necessary and not only what has been requested or that is his } \\
\text { responsibility; } \\
\text { - Collaborates with employees or puts himself in their place, if necessary, to get a } \\
\text { job done; } \\
\text { - Strives to keep customers satisfied and places long-term goodwill over short-term } \\
\text { gain }\end{array}$ \\
\hline $\begin{array}{c}\text { Systematic Planning } \\
\text { and Monitoring (SPM) }\end{array}$ & $\begin{array}{l}\text { - Plans dividing large goals into sub-tasks with defined deadlines; } \\
\text { - Keeps financial records and uses them to make business decisions; } \\
\text { - Revises plans in the light of feedback on performance or changing circumstances }\end{array}$ \\
\hline $\begin{array}{l}\text { Persuasion and } \\
\text { Networking (PN) }\end{array}$ & $\begin{array}{l}\text { - Uses deliberate strategies to influence others; } \\
\text { - Uses key people as agents to accomplish own objectives; } \\
\text { - Acts to develop and maintain business contact }\end{array}$ \\
\hline $\begin{array}{l}\text { Independence and Self- } \\
\text { confidence (ISC) }\end{array}$ & $\begin{array}{l}\text { - Seeks autonomy from the rules and control of others; } \\
\text { - Sticks with own judgment in the face of opposition or early lack of success; } \\
\text { - Expresses confidence in own ability to complete a difficult task or meet a } \\
\text { challenge }\end{array}$ \\
\hline
\end{tabular}

Source: Adapted from Cooley (1990) by the authors.

In addition to these factors, studies have identified the internal locus of control as an important characteristic in defining entrepreneurial behavior (BROCKHAUS, 1982). The concept of control locus formulated by Rotter (1966) means that people develop expectations and beliefs about a causal connection between their actions and the results they achieve. Those 
who believe they can interfere in the results because of their behavior, skills and effort are those who believe in the Internal Locus of Control (ILC).

Along with the individual characteristics, the development of entrepreneurship at the corporate level needs the presence of certain organizational conditions that foster the manifestation of entrepreneurial behavior. In other words, $\mathrm{CE}$ is a process that is not restricted only to the actions of individuals, the organizational structure being seen as a fundamental element for its existence (HORNSBY; MONTAGNO; KURATKO, 1992; HUGHES; MUSTAFA, 2017; URBAN, 2017).

Hornsby, Montagno and Kuratko (1992) developed an instrument, called the Corporate Entrepreneurship Assessment Instrument (CEAI), with the objective of measuring organizational conditions identified as necessary for internal entrepreneurship, based on five factors: managerial support, availability of time, autonomy/work criterion, rewards/reinforcement and clarity of roles. Regarding Management Support, the authors indicated that it refers to the willingness of senior management to promote entrepreneurship through the promotion of innovative ideas and making available resources for these initiatives. Some measures of managerial support would be: the rapid adoption of employees ideas, recognition of people implementing new ideas, support for small experimental projects and financial resources for new projects.

The Autonomy/Work Criterion represents the ability of top management to tolerate failures, provide freedom of action, and delegate authority/responsibility to managers. The Rewards/Reinforcement factor refers to the development and use of performance-based reward systems to encourage challenging work. Allowing employees Availability of Time to pursue innovation and achieving organizational goals is the fourth factor in analyzing the organization's conditions for CE. Finally, Clarity of Roles is defined as precise explanations of the expected results of organizational work, as well as the existence of evaluation mechanisms (KURATKO; HORNSBY; GOLDSBY, 2004).

Thus, in the context of an organization, an employee would be motivated towards entrepreneurial behaviors when his initiatives are, at the same time, viable, when management concedes the time, resources, and support, and desirable, when they bring with them compatible rewards (BRAZEAL, 2004).

\subsection{Tools for Evaluating the Background of Corporate Entrepreneurship}

\subsubsection{Tools for evaluating Personal Entrepreneurial Characteristics (PECs)}

In this paper, we used the set of individual characteristics and behaviors identified in successful entrepreneurs by McClelland et al. (1987), reviewed by Cooley (1990) and revised by the authors. We also used the instrument called Gletest. Gletest is a self-assessment tool with 105 statements, which seeks to identify the profile of an individual, or group, in relation to the ten characteristics of entrepreneurial behaviors observed by McClelland et al. (1987) and Cooley (1990), in addition to the internal locus of control (ILC). 
For each statement of the test, the respondent makes a self-assessment based on a Likert scale. The final score, which measures the intensity of each trait, is determined by means of a structured sequence of sums and subtractions. This instrument uses a correction factor to mitigate possible distortions in the results, caused by biased answers on the part of the respondent.

For each organization where the instrument is applied, the system automatically generates a graph for each respondent and the average profile of the managers evaluated. This average permits the evaluation of the entrepreneurial characteristics most present in the group and indicates those that need to be developed.

\subsubsection{Tools for evaluating Organizational Characteristics}

The CEAI (Corporate Entrepreneurship Assessment Instrument) was developed by Hornsby, Montagno and Kuratko (1992) from the improvement of the IAI - Intrapreneurial Assessment Instrument - developed by Kuratko, Montagno and Hornsby (1990). The CEAI has been considered promising by researchers and consultants, since it is relatively concise, uses psychometric techniques and measures organizational conditions that indicate the action to be taken to develop intrapreneurship (Davis, 2006).

Hornsby, Kuratko, and Zahra (2002) improved the CEAI and elaborated five constructs evaluated by 48 questions. Cates (2007) revised the original CEAI, and established 24 questions instead of the original 48, in addition to reworking constructs and questions. This new test showed evidence of being a powerful tool for evaluating the organizational conditions that promote organizational entrepreneurship (CATES, 2007).

\section{METHODOLOGY}

After reviewing the literature, we chose to use the CEAI test, modified by Cates (2007), to measure the managers' perception of the presence of the organizational factors that determine $\mathrm{CE}$. In order to evaluate personal entrepreneurial characteristics we used the Gletest instrument for the self-evaluation of the PECs. Gletest, although widely used in corporate entrepreneurship development programs, has undergone validity and reliability testing. The objective was to refine the instrument, as Cates (2007) had done with the CEAI, to evaluate organizational conditions.

The first part of our research, therefore, was to verify the validity and reliability of Gletest to measure the individual entrepreneurial characteristics. We performed this verification by statistically analyzing the data collected. In addition, we analyzed the possible correlations between the presence of organizational factors and individual characteristics. The survey of individual characteristics (PECs) has been carried out since 2006, with the application of Gletest in 548 managers participating in corporate entrepreneurship training. These data were obtained in 19 groups, composed of managers of 11 large public and private organizations (over 250 employees). 
The survey of organizational characteristics, using the CEAI test, was conducted between 2010 and 2011 with 184 company managers submitted to the same intrapreneurship training. The sample of managers surveyed with the CEAI in large public and private organizations was as follows: Public Company A - 54 managers; Public Company B - 54 managers; Public Company C - 18 managers; Private Company - 19 managers and 35 different Private Companies - 39 managers.

The sample of the 548 respondents was only used integrally for the first part of the research, that is, to verify the validity and reliability of the Gletest, of self-evaluation of the PECs. The second part of the research involved applying the two instruments, CEAI and Gletest tests, to managers of large companies, to meet the objectives of evaluating individual profiles, organizational factors and to verify the possible correlations between these antecedents of Corporate Entrepreneurship.

To facilitate the visualization of the tables and tables, we adopted the abbreviations of the PECs (Table 1).

For the same purpose and to preserve the identity of the companies surveyed, we refer to organizations as:

1. PHC - Privately Held Company

2. PC.a- Public Company a

3. PC.b - Public Company b

4. $\quad$ PC.c - Public Company c

5. Several managers - Managers of 35 private companies

\section{ANALYSIS AND DISCUSSION OF RESULTS}

\subsection{Verification of validity and reliability of Gletest (self-evaluation personal entrepreneurial characteristics - PECs)}

As mentioned in the introduction to this paper, one of our objectives was to raise and analyze instruments for evaluating individual entrepreneurial characteristics and organizational conditions, composing what we could classify as a model for assessing the antecedents of corporate entrepreneurship. When the survey was carried out, we found that the CEAI test, which evaluated organizational conditions, had been subjected to several refinement processes (ADONISI, 2003; CATES, 2007; DAVIS, 2006; HORNSBY; KURATKO; ZAHRA, 2002). However, the instrument used for self-assessment of PECs, Gletest, had not undergone a validation process. In this sense, we decided that the instrument should undergo an evaluation of validity and reliability.

According to Hair et al. (2009), there are three ways of assessing validity quantitatively: convergent, discriminant and nomological. Convergent validity assesses the degree to which two measures of the same concept are correlated. Discriminant validity is the degree to which two similar concepts are correlated, but conceptually distinct. Nomological validity refers to the degree to which the multiple scale makes accurate predictions compared to other theoretical models. 
We verified the unidimensionality of each construct using the following methods: Kaiser (1958), Optimal Coordinates and Acceleration Factor (RAÎCHE; RIOPEL; BLAIS, 2006) and Parallel Analysis (HORN, 1965). These criteria return the number of factors that must be retained in the principal component analysis (factorial analysis), that is, the number of dimensions of the construct. To verify the internal consistency of each construct, we used the Spearman Correlation (HOLLANDER; WOLFE, 1999). We also used Cronbach's Alpha Coefficient to measure reliability. To verify the concept of validity, we used only two (discriminant and convergent) of the three forms mentioned above. We did not use the nomological validation because this involves the comparison with already validated theoretical models. For the discriminant validity we used the Pearson Correlation, since the final values of each construct presented normal distribution. Convergent validation was verified with factorial analysis. The software used in the analysis was $\mathrm{R}$ version 2.11.1.

There are four basic questions for constructing and validating any multiple scale (construct): conceptual definition, dimensionality, reliability, and validity. As the constructs already have the conceptual definitions based on theory, we present below the analysis of dimensionality, reliability and validity (HAIR et al., 2009).

As a result of the analysis carried out, we came to some conclusions about the validity and reliability of the original Gletest (105 questions). The unidimensionality was verified for all the constructs by at least one of the estimation criteria (Kaiser, Parallel Analysis, Optimal Coordinates and Accelaration Factor) of the factor numbers to be retained in the factorial analysis. In addition, by analyzing the variances to be reached by the first factor, we did not obtain any measure of percentage, considering only one dimension, below the $20 \%$ proposed by Reckase (1979) and none exceeding 40\%, recommended by Carmines and Zeller (1979). Thus, by virtue of these results, we can consider the one-dimensional constructs. The reliability requirements were not verified for the MRT, QER and ILC constructs through Cronbach's Alpha measure.

Discriminant validity was not achieved either. However, this result was already expected, due to the well-known correlations between some constructs. We highlight the strong correlations between Goal Setting and Systematic Planning and Monitoring, Persistence and Independence and Self-confidence, and Information Seeking with Systematic Planning and Monitoring. Likewise, the convergent validity was not achieved, since we observed in all the constructs at least two individual factor loads less than 0.5, proposed by Hair et al. (2009). This fact suggests that there are many questions in the constructs, inducing to other dimensions and reducing the factor loads.

Thus, the results of the dimensionality and validity analyses of the constructs suggested the withdrawal of questions from Gletest for the self-assessment of the PECs. By reducing the number of items, we would follow the principle of parsimony, making the test less tiring and free of questions that contribute little to the evaluation of the constructs, thus increasing the quality and efficiency of the measurement performed by the questionnaire

Therefore, we changed the questionnaire, removing the questions that presented lower factor loads. Two questions were taken from the internal locus of control construct and four 
items from each of the other constructs. The new questionnaire consisted now of 63 instead of the 105 questions from the original Gletest.

After the exclusions, we started the reduced Gletest evaluation, with 63 questions. Thus, we repeated the statistical analyses, performed in the first stage, to verify the validation of the modified test according to the concepts of dimensionality, reliability, convergent and discriminant validity.

At that time, we asked about the validity of the reduced test. First, would the withdrawal of 42 questions not create another test, considerably different from the original Gletest, which, in this way, would produce different results when applied? Second, to validate the reduced test would we not have to apply it, and then evaluate the reliability and validity from the new data collected?

Regarding the first questioning, we adopted a procedure to verify if the new test would generate a considerably different profile (graph). Using the responses from the sample of 548 applied tests, we calculated the average score of the original Gletest (105 items) and also the reduced test (63 items), excluding the answers of the questions withdrawn. The objective of this analysis was to verify if, between the two tests, there were significant differences in the profiles generated for the PECs.

Thus, we observed that OSI, MRT and ILC are the characteristics with the lowest scores in the two tests. Likewise, in both tests the characteristics with the highest scores are the same: PER, COM and IS. In addition, we identified a great similarity between the two tests' curves, demonstrating that the reduced test does not significantly alter the patterns found. Thus, we conclude that the withdrawal of the questions did not change the standards of results.

Regarding the second questioning, the similarity between the profiles generated by the two tests already suggests that the application of the reduced questionnaire will produce similar results. In addition, the original test contained many issues with low factor load and constructs with low reliability. This means that these items could be generating confusion, fatigue or inattentiveness in the respondents, and thus contributing little to the evaluation of the constructs.

The new measurement model (63 questions) achieved unidimensionality in at least one of the methods used (Kaiser, Optimal Coordinates, Acceleration Factor and Parallel Analysis). In addition, we verified the unidimensionality by the percentage of variance retained in the first factor for all the constructs. These results allow us to consider that all constructs are onedimensional.

The reliability or internal consistency, as measured by Cronbach's Alpha, was achieved in all constructs, with the exception of MRT. The MRT construct showed Cronbach's alpha equal to 0.481, lower than 0.6, suggested by Hair et al. (2009). We also verified, through the Spearman Correlation Matrix, that only one question of the MRT construct did not reach the desired measure for reliability.

However, this evaluation was done with the original Gletest database, which was certainly "contaminated" with responses generated by the excessive number of questions, which contributed little to the evaluations of the constructs. In this way, it is possible that the evaluation will achieve reliability for this construct, after the application of the reduced test. 
We also found evidence of convergent validity, through factor loading and Bootstrap Analysis, since, with the exception of one item in the MRT construct, all other factor loads found were satisfactory.

As expected, as well as in the statistical analysis of the original test (105 items), discriminant validity was not reached, due to the existence of strong correlations between some constructs.

It should be noted that in the reduced test the correlations between the totals of the constructs decreased considerably. Thus, even if the objective is not to reach discriminant validity, because of the strong correlations between some constructs, we can conclude that the reduced Gletest is better than the original version.

Since the profile generated by the original test resembles that generated by the reduced test, we also noticed that the original test, although not presenting the appropriate statistical properties (such as the 63 items questionnaire) was a tool that allowed the evaluation of the individual profile of PECs in a similar way to the new questionnaire.

The conclusions above suggest that special attention should be given to the questions that make up the MRT construct. We expect that the reliability and validity of this construct will present better results in a future analysis of data obtained through the application of the reduced test. However, if this does not occur, it will be appropriate to review the items of this construct.

After completing the verification of the validity and reliability of the reduced Gletest (self-assessment of the PECs), we proceeded to analyze the PECs and CEAI profiles in the five groups of organizations surveyed and to verify the possible correlations between the presence of organizational factors (CEAI test) and the individual entrepreneurial characteristics (Gletest).

\subsection{Results of the application of CEAI and Gletest tests in large organizations}

The second objective - to apply the instruments of evaluation of the antecedents of the $\mathrm{CE}$ in large organizations - has been fulfilled as follows. After the validity and reliability analysis of reduced Gletest (63 items), we applied the CEAI test to managers of large organizations. From the 548 Gletests sample, we selected the test data applied in these companies, using only the reduced test responses.

Thus, in Table 2, we present the means of each construct of the CEAI and Gletest tests for each organization.

Table 2 - Averages of each company according to the constructs of the Gletest and CEAI tests

$\begin{array}{cccccc}\text { CEAI and Gletest } & \text { PC.a } & \text { PHC } & \text { PC.b } & \text { PC.c } \\ \text { Management Support } & 2,43 & 2,80 & 2,46 & 2,53 & 3,88 \\ \text { Clarity of roles } & 3,46 & 3,43 & 3,45 & 2,71 & 2,62 \\ \text { Reward/Reinforcement } & 2,58 & 3,07 & 2,80 & 2,86 \\ \text { Availability of time } & 2,97 & 2,87 & 2,32 & 2,77 \\ \text { Autonomy } & 2,84 & 3,29 & 2,69 & 12,50 \\ \text { OSI } & 13,06 & 12,83 & 12,86 & 17,98 \\ \text { PER } & 18,84 & 18,89 & 18,50 & 13,68 \\ \text { COM } & 19,05 & 18,50 & 18,73 & 19,22 \\ \text { QER } & 17,97 & 18,39 & 18,11 & 19,03 \\ \end{array}$




\begin{tabular}{cccccc} 
MRT & 12,62 & 12,88 & 13,14 & 13,86 & 13,59 \\
GS & 14,96 & 16,06 & 14,77 & 14,78 & 16,53 \\
IS & 18,61 & 18,56 & 18,12 & 18,22 & 18,02 \\
SPM & 15,49 & 16,53 & 15,52 & 16,58 & 15,73 \\
PN & 14,50 & 16,31 & 15,17 & 15,31 & 16,38 \\
ISC & 15,59 & 15,95 & 15,41 & 15,37 & 16,09 \\
ILC & 14,66 & 15,13 & 14,68 & 14,17 & 15,93 \\
\hline \multicolumn{7}{r}{}
\end{tabular}

Source: Research data - prepared by the authors

As in the sample we have public companies (PC.a, PC.b and PC.c) and private ones (PHC and Several Managers), we present the Graphs 1, 2, 3 and 4 with the mean scores of the Gletests applied and Graphs 5,6 and 7 with the average scores of the CEAI, for each type of organization.

\section{Graph 1 - Profiles of average scores of companies' Glestests and general average}

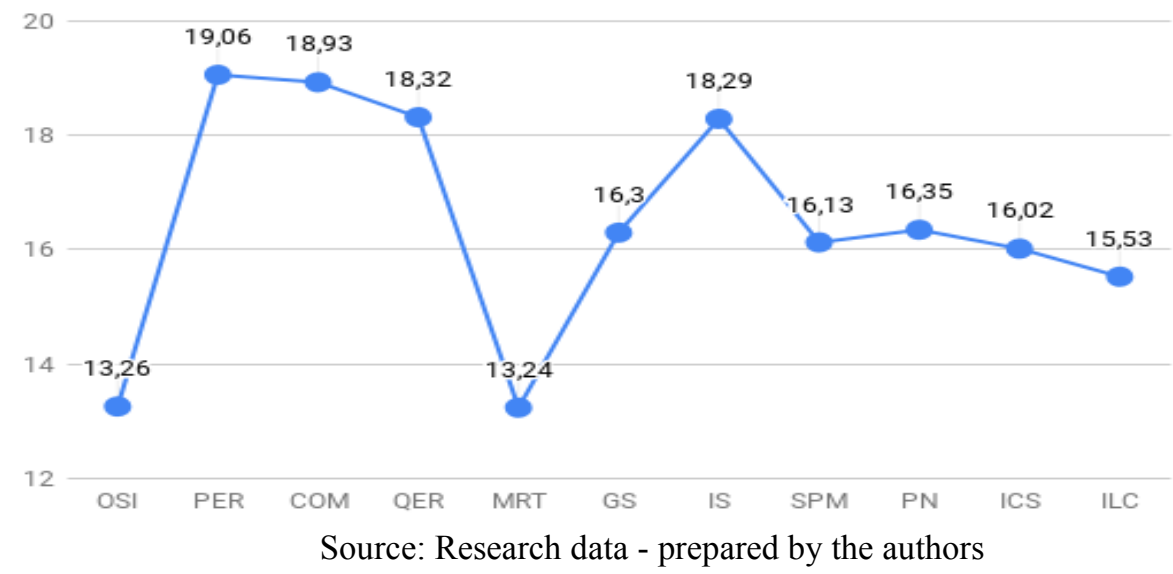

Graph 2 - Public companies PECs

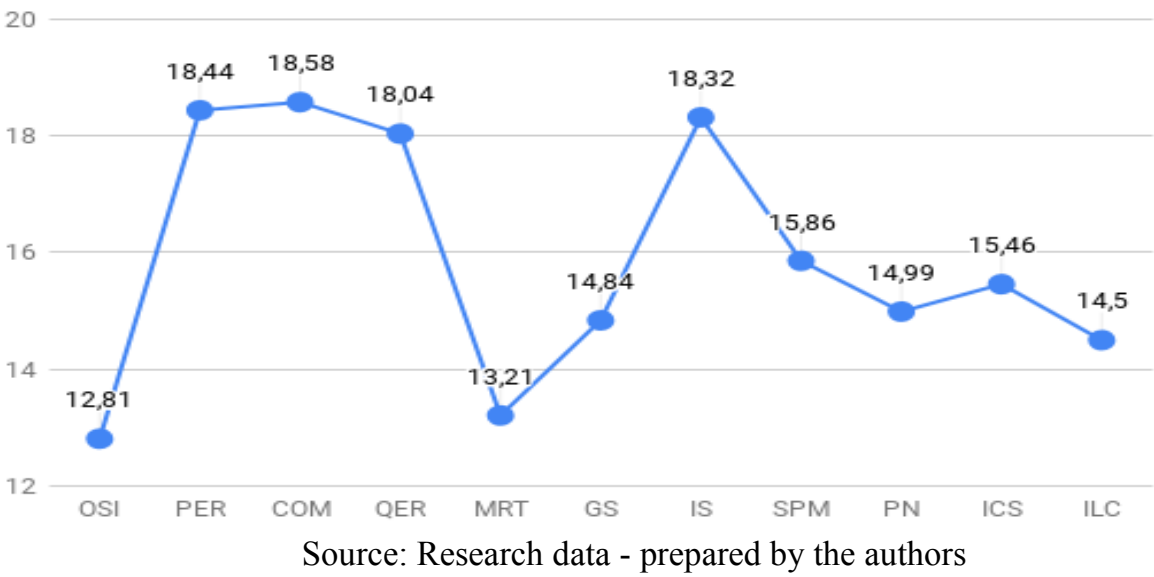

Graph 3 -General average 


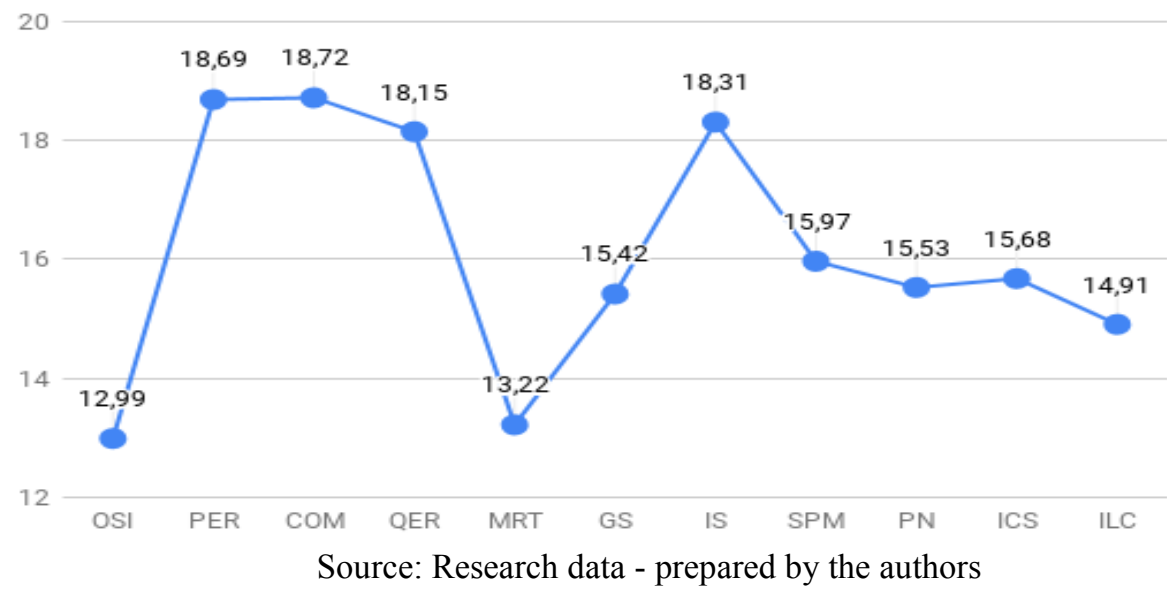

Graph 4 - Comparative of PECs

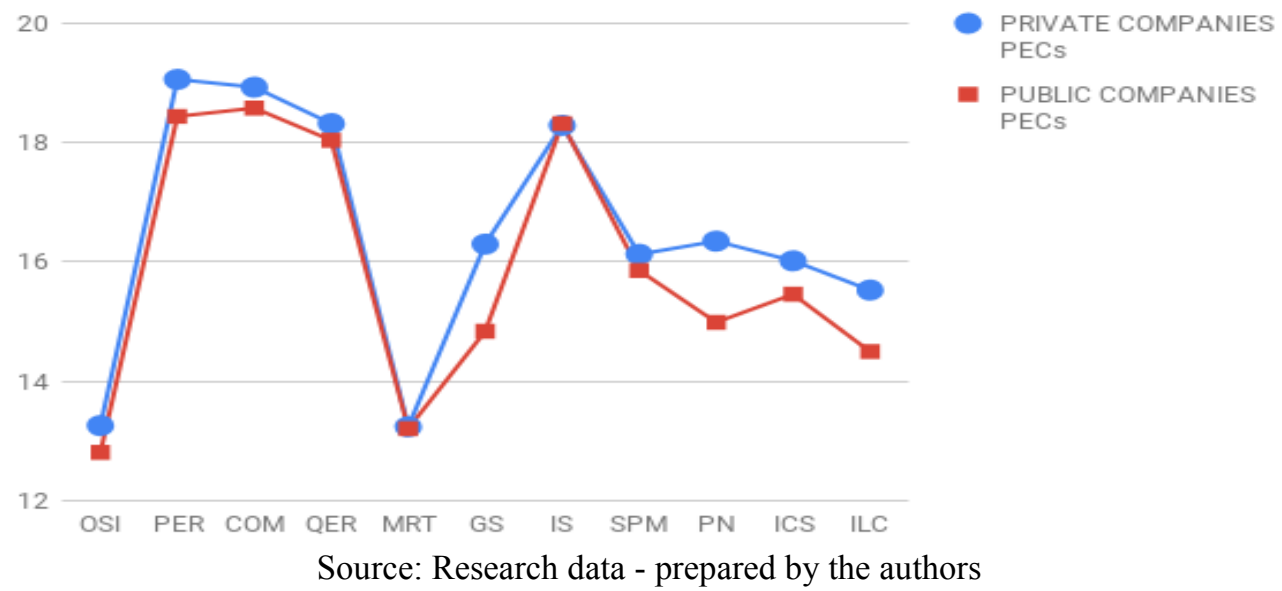

Graph 5 - CEAI test profiles of public, private and general average companies 4,0

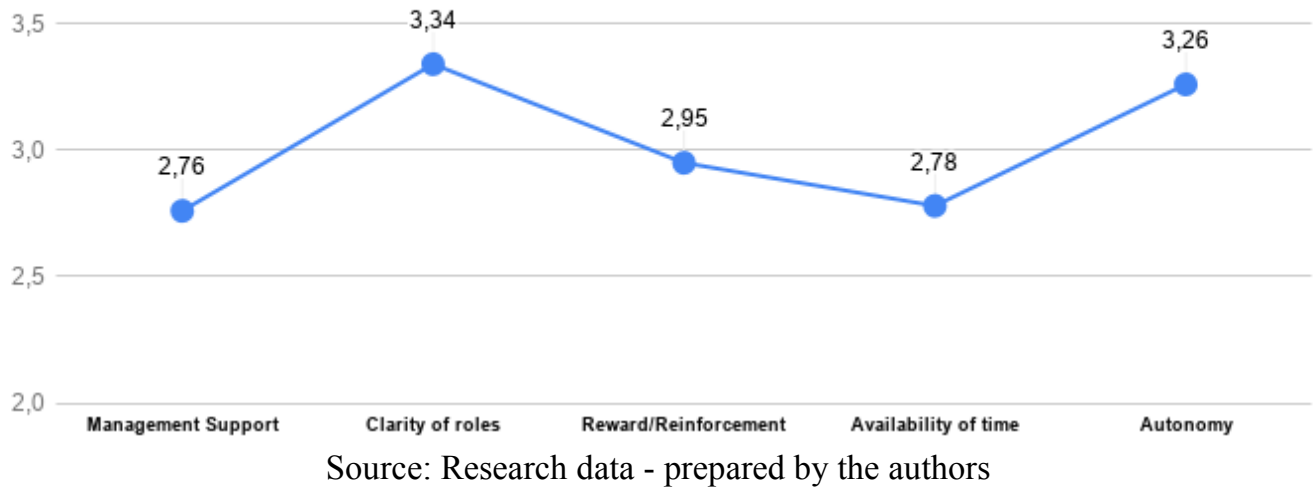




\section{Graph 6 - Public companies CEAI}

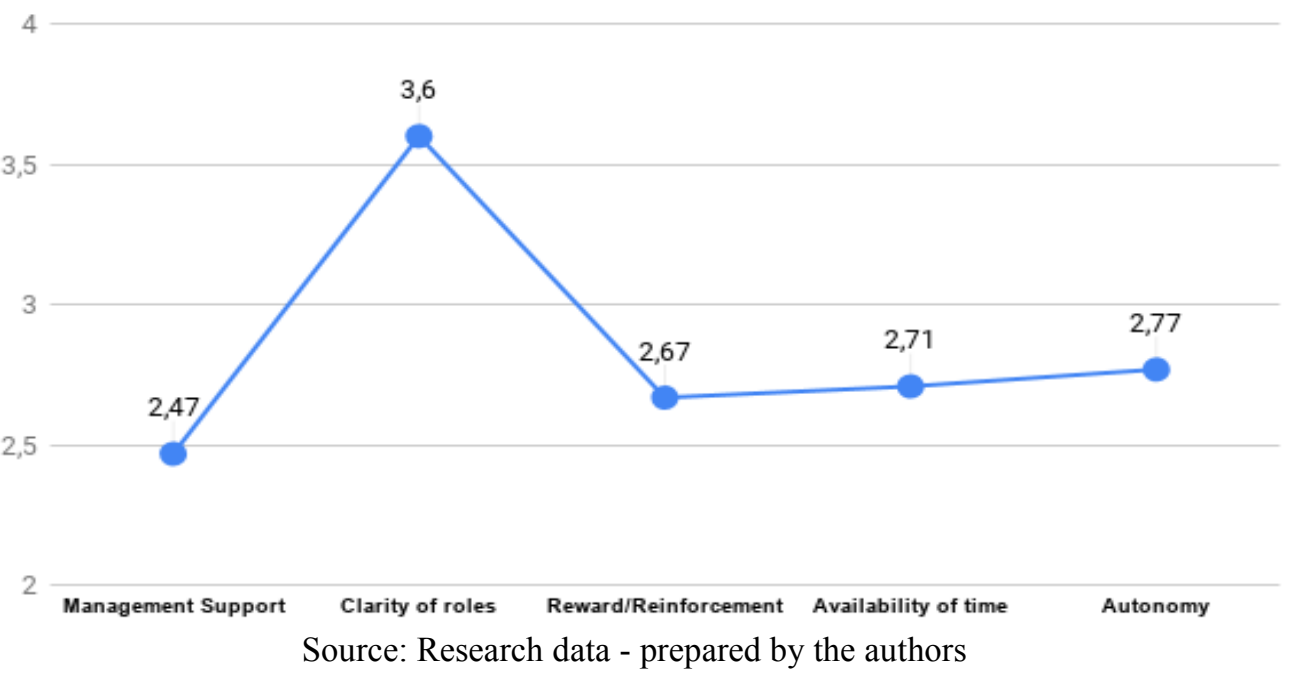

\section{Graph 7 -General average}

4

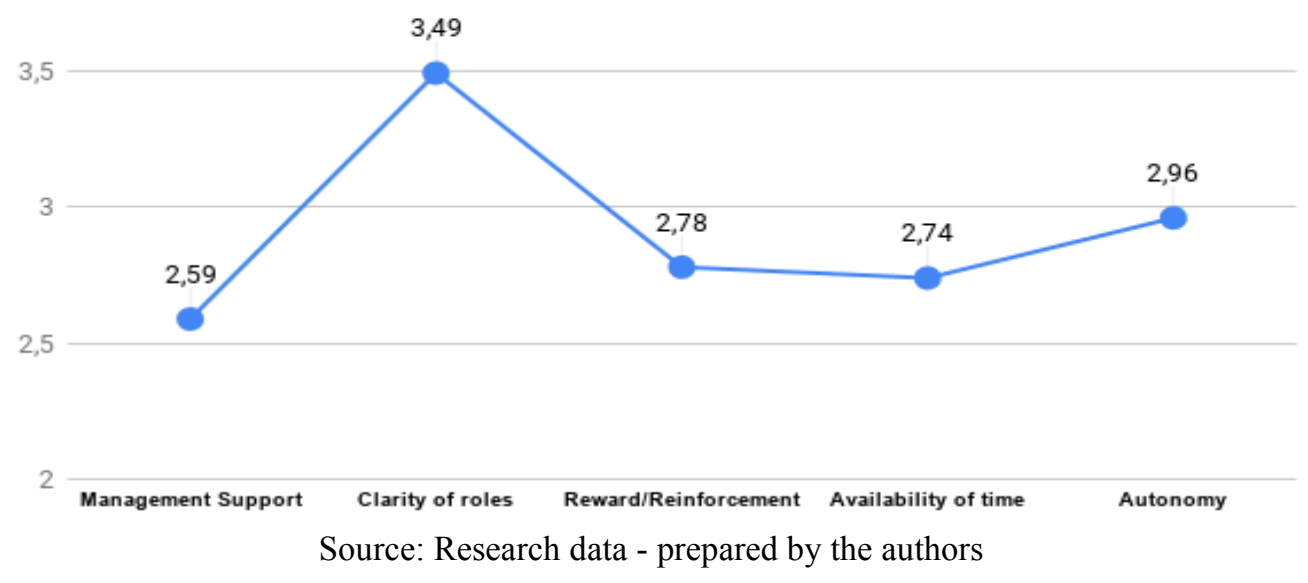

When analyzing the profiles of Graph 4, we found that there are differences between the average of the personal entrepreneurial characteristics (PECs) of the managers of the private companies and the public companies evaluated. It can be noticed that, in private organizations, managers present higher scores in all PECs, with the exception of MRT and IS that present similar averages in both groups. The greatest differences were observed in the PER, GS, PN, IS and ILC constructs.

In both types of organizations (public and private), we identified that the higher scores PECs are PER, COM, QER and IS, while MRT, OSI and ILC have the lowest scores. It is interesting to note that the constructs with the least scores (OSI, MRT and ILC) are characteristics that do not conform to the rigidity of norms and regulations, characteristic of large organizations. As noted in the theoretical framework, for some authors such as Luchsinger 
and Bagby (1987) and Reilly and Diangelo (1987), the classical bureaucracy with its rigidity, conservatism, risk aversion and structural slowness creates an inhospitable environment for initiative, innovation and opportunities that can be pursued.

We also observed that, except for Clarity of Roles and Availability of Time, all other organizational factors are more present in private than public companies. The Clarity of Roles is the only construct that is most perceived in public enterprises and Availability of Time is a perceived factor with similar intensity; we believe that this is evidence that this strong point (Clarity of Roles) and this weak point (Managerial Support) are characteristic of the average profiles of large organizations.

We found that the groups composed of PC (private companies) and Several Managers (managers from 35 private companies) were the ones that had the highest averages both in Gletest and CEAI tests.

When analyzing the results, we noticed that the great majority of the correlations between the constructs is positive. The most significant positive correlations are between Reward/Reinforcement and QER, Availability of Time and IS, and between the perception of Autonomy and the OSI, PER, GS and IS constructs.

The higher the perceived Reward/Reinforcement the higher the Quality and Efficiency Requirements. Likewise, we understand that the greater the perception of the Availability of Time, the higher the Information Seeking. Finally, the higher the perception of Autonomy in organizations, the greater the Opportunities Seeking and Initiative, Persistence, Goal Setting and Independence Self-confidence.

Therefore, there are strong evidence that the higher the perception of reward/reinforcement the higher the quality and efficiency score. Similarly, the higher the perception of time availability, the higher the information seeking score. Hitherto, the higher the autonomy within organizations, the higher the Opportunity Search and Initiative, the Persistence, the Goal Setting and the Independence Self-confidence scores.

Among the negative correlations, there is a significant difference between the Clarity of Roles and ILC, that is, there is a tendency that the higher the perception of the managers of the Clarity of Roles, the lower the score of the internal locus of control construct.

\section{CONCLUSIONS}

As mentioned previously, the stimulus to corporate entrepreneurship (CE) represents a relevant issue for the survival of organizations considering the fierce competition and constant changes in the global economic scenario. A fundamental point in this search by scholars and managers is how to diagnose the presence of the antecedents of $\mathrm{CE}$ and also how to measure them. From this diagnosis, both researchers and managers can analyze the organizational context by rethinking management practices in order to stimulate intrapreneurship.

In the review of the literature, we find several authors who agree that $\mathrm{CE}$ is a consequence of the interaction between individual and organizational characteristics. In this way, we seek to identify studies of personal entrepreneurial characteristics and organizational 
factors. In our search for work identifying the characteristics of successful entrepreneurs, we did not find any survey as large and consistent as the work done by McClelland et al. (1987).

Due to the refinements made in Gletest, we believe that, in the next research, using the reduced model, the results of reliability, convergent validity and unidimensionality will be even better. The reduced Gletest better meets the statistical principle of parsimony, since smaller questionnaires have lower rates of inconsistent responses. The result of these refinements is a validated model to jointly evaluate the antecedents of CE. After these considerations, we believe that the proposed model, made up of revised and validated tools, presents better consistency and would be suitable for use by managers interested in promoting corporate entrepreneurship.

Thus, after applying the model composed of the two instruments in a sample of managers of large organizations, we observed a trend in individual (PECs) and organizational profiles (CEAI factors). When we compare the average profiles resulting from the tests (Gletest and CEAI) between the private enterprise groups (PHC and Several Managers) and public companies (PC.a, PC.b and PC.c), we again noticed that private companies present the highest means in both tests. These results suggest that the challenge to develop $\mathrm{CE}$ in large public organizations is even greater. On the other hand, this identification of the points to be worked on individuals and organizational factors, can contribute to the adoption of more efficient measures for the development of intrapreneurship.

In a second moment, we identified the possible correlations between the managers' perception of the degree of presence of the organizational factors and the individual entrepreneurial characteristics (PECs). The first finding is that the great majority of the correlations between the constructs is positive, that is, there is a tendency to observe higher scores of the PECs profiles where higher scores of the CEAI factors are observed.

However, statistical analyses do not identify whether the most present organizational factors that influence individual characteristics are the opposite, or whether a high profile of entrepreneurial characteristics influences a higher perception of the presence of organizational factors. Clarifying this issue would make a good suggestion for future research.

However, we understand that the most significant positive correlations identified suggest that it is the organizational factors that influence the individual entrepreneurial characteristics rather than the reverse. Authors claim that for the development of intrapreneurship, it is necessary for members of the organization to respond to the incentives of management to adopt entrepreneurial attitudes. Thus, from the applied tests, it seems logical to affirm that the continuous search for the improvement of quality and efficiency, by a part of the individuals of an organization, is increased from the moment that such initiatives are recognized or rewarded.

Finally, we also believe that it is the greater perception of autonomy in companies that generates a greater score of the constructs pursuit of opportunity, persistence, establishments of goals and independence self-confidence. The perception of autonomy and the absence of excessive supervision allow initiative to manifest itself, the search for new business, establishment of individual objectives, perseverance in the face of obstacles and, of course, greater Independence and Self-confidence. 
However, we encountered some limitations. Due to the size of the sample used in this work, there was a certain limitation in extrapolating the results found to all types of organizations. Likewise, there is a prevalence of public companies in the sample, since the number of managers surveyed in public companies (126) is more than double the sample of managers (58) from the private sector. In addition, because of the difficulty of all managers in responding to the tests, our sample does not have a statistical representation of the managers of all the hierarchical levels of the companies surveyed.

A broader study can be conducted across diverse organizations to identify how entrepreneurial attitudes and perceptions of organizational factors differ between the strategic, tactical and operational hierarchical levels. Finally, among other studies, one can investigate how individual and organizational factors are correlated at these three hierarchical levels.

\section{REFERENCES}

BABAK, Z. Presenting an evaluation model of human resource management's effect on corporate entrepreneurship. World Journal of Entrepreneurship, Management and Sustainable Development, v. 12, n. 3, p. 228-242, 2016.

Bloodgood, J. M.; Hornsby, J. S.; Burkemper, A. C. \& Sarooghi, H. A system dynamics perspective of corporate entrepreneurship. Small Business Economics, 45, 383-402, 2015.

Brazeal, D. V. The feasibility \& desirability of corporate entrepreneuship: unwrapping the black box of entrepreneurial potential. U.S. Association of Small Business \& Entrepreneurship.

Disponível

em:

http://usasbe.org/knowledge/proceedings/proceedingsDocs/USASBE2004proceedings-

Brazeal.pdf. 2004. Acesso em: 30 mai. 2011.

BROCKHAUS, R. H. The psychology of the entrepreneur. In: KENT, C. A.; SEXTON, D. L.; VESPER, K. H (Ed.). Encyclopedia of Entrepreneurship. Englewood Cliffs: Prentice-Hall, 1982, p. 39-57.

CARMINES, E. G.; ZELLER, R. A. Reliability and validity assessment. Thousand Oaks/London/New Delhi : Sage Publications, 1979.

CATES, M. S. Corporate Entrepreneurship Assessment Instrument (CEAI): Refinement and Validation of a Survey Measure. 2007. $80 \mathrm{f}$. Thesis (Master of Science in Information Resource Management) - Department of Systems and Engineering Management, Air Force Institute of Technology, Wright-Patterson, 2007.

COOLEY, L. Entrepreneurship training and the strengthening of entrepreneurial performance. Final Report. Washington: USAID, 1990.

DAVIS, T. M. Corporate entrepreneurship assessment instrument (CEAI): Systematic validation of a measure. 2006. $88 \mathrm{f}$. Thesis (Master of Science in Information Resource Management) - Department of Systems and Engineering Management, Air Force Institute of Technology, Wright-Patterson, 2006.

FERRAS, R. P. R. et al. Empreendedorismo Corporativo em Organizações Públicas. Revista de Empreendedorismo e Gestão de Pequenas Empresas - REGEPE, v.7, n.2, 2018.

HAIR, J. F. et al. Análise multivariada de dados. Porto Alegre: Bookman, 2009. 
HOLLANDER, M.; WOLFE, D. A. Nonparametric Statistical Methods. New York: Wiley, 1999.

HORN, J. L. A rationale and test for the number of factors in factor analysis. Psychometrika, v. 30, n. 2, p. 179-185, 1965.

HORNSBY, J. S. et al. An interactive model of the corporate entrepreneurship process.

Entrepreneurship: Theory and Practice, v. 17, n.2, p.29-37, 1993.

HORNSBY, J. S.; KURATKO, D. F.; MONTAGNO, R. V. Perception of internal factors for corporate entrepreneurship: A comparison of Canadian and US managers. Entrepreneurship Theory and Practice, v. 24, n. 2, p. 9-24, 1999.

HORNSBY, J. S.; MONTAGNO, R. V.; KURATKO, D. F. Critical organizational elements in corporate entrepreneurship: An empirical study. Academy of Management, v. 52, 1992.

HORNSBY, J. S.; KURATKO, D. F.; ZAHRA, S. A. Middle managers' perception of the internal environment for corporate entrepreneurship: assessing a measurement scale. Journal of business Venturing, v. 17, n. 3, p. 253-273, 2002.

HUGHES, M.; MUSTAFA, M. Antecedents of corporate entrepreneurship in SMEs: Evidence from an emerging economy. Journal of Small Business Management, v. 55, p. 115-140, 2017.

KAHKHA, A. O. et al. Corporate entrepreneurship and firm performance important role of small and medium enterprise. International Journal of Academic Research in Business and Social Sciences, v. 4, n. 6, p. 8, 2014.

KAISER, H. F. The varimax criterion for analytic rotation in factor analysis. Psychometrika, v. 23, n. 3, p. 187-200, 1958.

KAMAU, J. N. Corporate Entrepreneurship Antecedents and Organization Performance in Kenya: An Empirical Study. The University Journal, v. 1, n.2, 2018.

KONTIĆ, L.; VIDICKI, D.; DOMANOVIĆ, V. Testing Corporate Entrepreneurship Assessment Instrument in Transition Environment. In: DIEM: DUBROVNIK INTERNATIONAL ECONOMIC MEETING, 3., 2017, Dubrovnik. Anais [...]. Dubrovnik: Univeristy of Dubrovnik, 2017. p. 67-78.

KURATKO, D. F.; AUDRETSCH, D. B. Clarifying the domains of corporate entrepreneurship. International Entrepreneurship and Management Journal, v. 9, n. 3, p. 323-335, 2013.

KURATKO, D. F.; HORNSBY, J. S.; GOLDSBY, M. G. Sustaining corporate entrepreneurship: modelling perceived implementation and outcome comparisons at organizational and individual levels. The International Journal of Entrepreneurship and Innovation, v. 5, n. 2, p. 77-89, 2004.

KURATKO, D. F. et al. Implement entrepreneurial thinking in established organizations. SAM Advanced Management Journal, v. 58, n. 1, p. 28-35, 1993.

KURATKO, D. F.; HORNSBY, J. S.; HAYTON, J. Corporate entrepreneurship: the innovative challenge for a new global economic reality. Small Business Economics, v. 45, n. 2, p. 245 $253,2015$. 
KURATKO, D. F.; MONTAGNO, R. V.; HORNSBY, J. S. Developing an intrapreneurial assessment instrument for an effective corporate entrepreneurial environment. Strategic Management Journal, p. 49-58, 1990.

KURATKO, D. F.; MORRIS, M. H.; SCHINDEHUTTE, M. Understanding the dynamics of entrepreneurship through framework approaches. Small Business Economics, v. 45, n. 1, p. 1$13,2015$.

MCCLELLAND, D. C. Characteristics of successful entrepreneurs. The Journal of Creative Behavior, v. 21, n. 3, p. 219-233, 1987.

MANSFIELD, R. S. et al. The identification and assessment of competencies and other personal characteristics of entrepreneurs in developing countries. Final Report. McBer and Compay. Massachusetts, 1987.

RAÎCHE, G.; RIOPEL, M.; BLAIS, J. G. Non graphical solutions for the Cattell's scree test. In: INTERNATIONAL MEETING OF THE PSYCHOMETRIC SOCIETY, 71., 2006, Montréal. Anais [...]. Montréal: HEC Montréal - Quebec, 2006.

RECKASE, M. D. Unifactor latent trait models applied to multifactor tests: Results and implications. Journal of Educational Statistics, v. 4, n. 3, p. 207-230, 1979.

REILLY, B. J.; DIANGELO JR, Joseph A. Entrepreneurial behavior in large organizations. SAM Advanced Management Journal, v. 52, n. 3, p. 24, 1987.

ROTTER, J. B. Generalized expectancies for internal versus external control of reinforcement. Psychological Monographs: General and applied, v. 80, n. 1, p. 1, 1966.

SATHE, V. Fostering entrepreneurship in the large, diversified firm. Organizational Dynamics, v. 18, n. 1, p. 20-32, 1989.

UNCTAD (2004). Entrepreneurship and Economic Development: The Empretec Showcase. Disponível em: $<$ http://www.unctad.org/en/docs/webiteteb20043_en.pdf $>$. Acesso em: 20 nov. 2018.

SEBRAE, Serviço Brasileiro de Apoio às Micro e Pequenas Empresas. Programa Empretec: manual de operacionalização. Brasília, SEBRAE. 2009

DA SILVA, M. V. G. et al. Intraempreendedorismo no Setor Público: Análise do Comportamento Empreendedor de Gestores Públicos Municipais por Meio do Carland Entrepreneurship Index (CEI). Revista de Empreendedorismo e Gestão de Pequenas Empresas, v. 7, n. 2, p. 67-114, 2018.

URBAN, B. Corporate entrepreneurship in South Africa: The role of organizational factors and entrepreneurial alertness in advancing innovativeness. Journal of Developmental Entrepreneurship, v. 22, n. 03, p. 1750015, 2017.

ZAHRA, S. A.; JENNINGS, D. F.; KURATKO, D. F. The antecedents and consequences of firm-level entrepreneurship: The state of the field. Entrepreneurship Theory and practice, v. 24, n. 2, p. 45-65, 1999. 